RADOVI

Zavoda za znanstveni rad HAZU Varaždin

NIKOLA SAKAČ

Sveučilište u Zagrebu, Geotehnički fakultet Varaždin
UDK 628.1: 556.3(497.524)“2006/2014“ Izvorni znanstveni članak Original Scientific Paper

Primljeno: 03. 02. 2016.

Prihvaćeno: 14. 09. 2016. DOI: http://doi.org/10.21857/90836cd2qy

NADA GLUMAC

Međimurske vode d.o.o., Čakovec

nada.glumac@medjimurske-vode.hr

IVAN KOVAČ

Sveučilište u Zagrebu, Geotehnički fakultet Varaždin

ivan.kovac@gfv.hr

\title{
DINAMIKA SADRŽAJA NITRATA, FOSFATA I DETERDŽENATA U PODZEMNOJ VODI VODOOPSKRBNOG SUSTAVA MEĐIMURSKE ŽUPANIJE
}

\begin{abstract}
Analizirani su podaci o laboratorijski utvrđenom sadržaju nitrata, fosfata i deterdženata u podzemnoj vodi u osmogodišnjem razdoblju od 2006. - 2014. godine na vodocrpilištima Nedelišće i Prelog na području Međimurja. Istraženi su utjecaj sadnje djeteline i intenzione poljoprivrede; te ovisnost količine oborina i razine podzemnih voda o koncentraciji nitrata u podzemnoj vodi.
\end{abstract}

\section{UVOD}

Međimurska županija bogata je podzemnim, pitkim i termalnim vodama visoke kvalitete. Na području Donjeg Međimurja nalaze se bogata nalazišta podzemnih voda. Za potrebe vodoopskrbe podzemne vode crpe se na dva vodocrpilišta Nedelišće i Prelog, koje čine temelj vodoopskrbe Međimurske županije.

Vodocrpilište Nedelišće sastoji se od šest zdenaca (Z1-Z6), a podzemna voda se crpi iz oba vodonosna sloja. Kapacitet crpljenja je 100 L/s po zdencu. Vodocrpilište Prelog sastoji se od dva zdenca, od kojih jedan crpi vodu iz prvog vodonosnog sloja (Z1), a drugi (Z2), koje je otvoren od 2012. godine, crpi vodu iz drugog vodonosnog sloja.

Važni pokazatelji antropogene aktivnosti na slivnom području podzemne vode su sadržaj nitrata, fosfata i deterdženata u podzemnim vodama. ${ }^{1}$ Praćenjem njihova 
sadržaja u vodi dobivamo saznanja o kvaliteti podzemnih voda temeljem kojih se osmišljavaju i provode kompleksne mjere zaštite voda.

Nitrati su negativno nabijeni ioni, dio su biološkog kruženja dušika kao biogenog elementa kojega biljke primaju upravo u nitratnom obliku i troše u većim količinama. Stoga su dušična mineralna gnojiva ključ visokih prinosa u poljoprivredi. Nitrati su jako topljivi, ne vežu se na koloidni kompleks tla pa se vrlo lako ispiru oborinskom vodom i dospijevaju u podzemne vode. Nalaze se u vrlo malim koncentracijama $u$ svakoj vodi. U podzemnim vodama koncentracije su manje od $3 \mathrm{mg} / \mathrm{L}$. Veće koncentracije upućuju na antropogeni utjecaj ili organsko onečišćenje vode. Do podzemnih voda nitrati dopiru iz različitih izvora: ispiranjem iz poljoprivrednih tala, cijeđenjem iz septičkih jama, raspadanjem biljnog i životinjskog otpada, iz geoloških ležišta nitratnih soli. ${ }^{2} \mathrm{U}$ prirodi uzrokuju eutrofizaciju, a kod ljudi methemoglobinemiju kod djece (redukcijom u nitrite) i druge štetne posljedice za zdravlje. Maksimalna dozvoljena koncentracija (MDK) nitrata u vodi za piće iznosi $50.0 \mathrm{mg} \mathrm{NO}{ }_{3} / \mathrm{L}^{2}{ }^{2}$

Fosfor je normalni sastojak biljaka, sastavni je dio kosti i zuba, mozga, mišića,živaca i DNA. Fosfor je esencijalan za rast organizama. Zbog pufernog djelovanja $u$ višim koncentracijama fosfati mogu prouzročiti probavne smetnje, a $u$ prirodi uzrokuju eutrofizaciju voda u vodotocima. MDK za fosfate u vodi za piće je $300 \mu \mathrm{g} / \mathrm{L}$.

Fosfor je također biogeni element. Javlja se u prirodnim i otpadnim vodama gotovo isključivo u obliku fosfata i to kao ortofosfati, kondenzirani fosfat (piro-,meta-,i drugi polifosfati) i organski vezani fosfor. Ovi oblici fosfata dolaze iz različitih izvora. Velike količine fosfata dospjevaju u vode pranjem i čišćenjem, jer su ti fosfati glavne sastavnice mnogih komercijalnih preparata za čišćenje, a donedavna i deterdženata, u kojima su zamijenjeni zeolitima. ${ }^{3}$ Ortofosfati su glavna sastavnica fosfornih mineralnih gnojiva. Primjenjeni kao gnojiva na poljoprivrednim tlima, unose se u površinske vode pritjecanjem erozijskog nanosa - suspenzije tla poslije jakih kiša i bujicama te manjim udjelom otapanjem snijega. Organski fosfati stvaraju se prvenstveno u biološkim procesima, a sastavni su dijelovi i organofosfornih insekticida.

Deterdženti čine sredstva za pranje na bazi sintetičkih površinski aktivnih tvari. Mogu biti anionski, kationski i neionski. Anionski deterdženti čine najveću udio u globalnoj proizvodnji deterdženata, i čine oko $60 \%$ ukupne proizvodnje. ${ }^{4}$ Imaju širok spektar upotrebe u raznovrsnim sredstvima za pranje. ${ }^{5}$ Neionski deterdženti su površinski aktivne tvari sa hidrofilnim i hidrofobnim značajkama, ali ne ioniziraju u vodenim otopinama. Neionski detergenti čine $30 \%$ ukupne globalne proizvodnje deterdženata. ${ }^{4}$ Nalaze se u mnogim formulacijama proizvoda - kao što su deterdženti za pranje rublja, za čišćenje i pranje suđa, te u proizvodima za osobnu higijenu. ${ }^{6}$ Kationski deterdženti koriste se za dezinfekciju. MDK za tenzide u vodi za piće $200 \mu \mathrm{g} / \mathrm{L}$. 
Cilj ovog rada bio je analizirati sadržaj nitrata, fosfata i deterdženata u podzemnoj vodi u razdoblju od 2006. - 2014. godine na vodocrpilištima Nedelišće i Prelog, te analizom godišnje količine i rasporeda oborina utvrditi njihov mogući utjecaj na razinu podzemnih voda.

\section{MATERIJALI I METODE}

Kvaliteta vode za ljudsku potrošnju iz vodoopskrbnog sustava Međimurske županije ispituje se prema Godišnjem planu uzimanja uzoraka vode za ljudsku potrošnju te se dobiveni podaci obrađuju i prikazuju u Godišnjim izvješćima, koja prikazuju minimalne maksimalne i srednje vrijednosti.

Sadržaj nitrata u vodi određuje se UV spektrofotometrijskom metodom u laboratoriju tvrtke Međimurske vode d. o. o. kontinuirano prema Godišnjem planu uzorkovanja.

Sadržaj fosfata u vodi se određuje ionskom kromatografijom prema HRN EN ISO 10304-1:2009 na Hrvatskom zavodu za javno zdravstvo četiri puta godišnje.

Deterdženti se određuju spektrofotometrijski: anionski prema HRN EN 903:2002 i neionski HRN ISO 7875-2:1998 na Hrvatskom zavodu za javno zdravstvo četiri puta godišnje. Do 2009. godine određivani su samo anionski detergenti, a od 2009. anionski i neionski detergenti.

Za obradu podataka korišten je MS Excel koji se nalazi u sklopu MS Office programskog paketa.

U radu su korišteni podaci dobiveni iz zdenaca na vodocrpilištima. Podaci o godišnjim količinama oborina dobiveni su iz interne evidencije dnevne količine oborina koja se vodi u tvrtci Međimurske vode d.o.o.

\section{REZULTATI I RASPRAVA}

\section{Nitrati}

Godišnji prosjeci koncentracije nitrata u podzemnoj vodi na vodocrpilištima Nedelišće (Slika 1) i Prelog (Slika 2) za razdoblje od 2006. do 2014. godine prikazani su na slici 3 (prosjek zdenaca). Vodocrpilište Prelog otvorilo je drugi zdenac (Z2, Prelog - polje) 2012. godine. Sve prikazane vrijednosti manje su od MDK. Koncentracije nitrata u zdencima vodocrpilišta Nedelišće pokazuju trend opadanja sve do 2010. godine, sa 18 na $10 \mathrm{mg} / \mathrm{L}$. Mišljenja smo da je više razloga zbog kojih je koncentracija nitrata opadala; 2006. godine prošireno je vodozaštitno područje Nadelišće otkupom privatnih poljoprivrednih parcela, i 2008. godine na tom vodozaštitnom području posijana je crvena djetelina (Trifolium pratense), koja je očito djelotvoran 
Nikola Sakač, Nada Glumac, Ivan Kovač: Dinamika sadržaja nitrata, fosfata i deterdženata u podzemnoj vodi...

Radovi Zavoda za znanstveni rad HAZU Varaždin, br. 28, 2017., str. 31 - 40

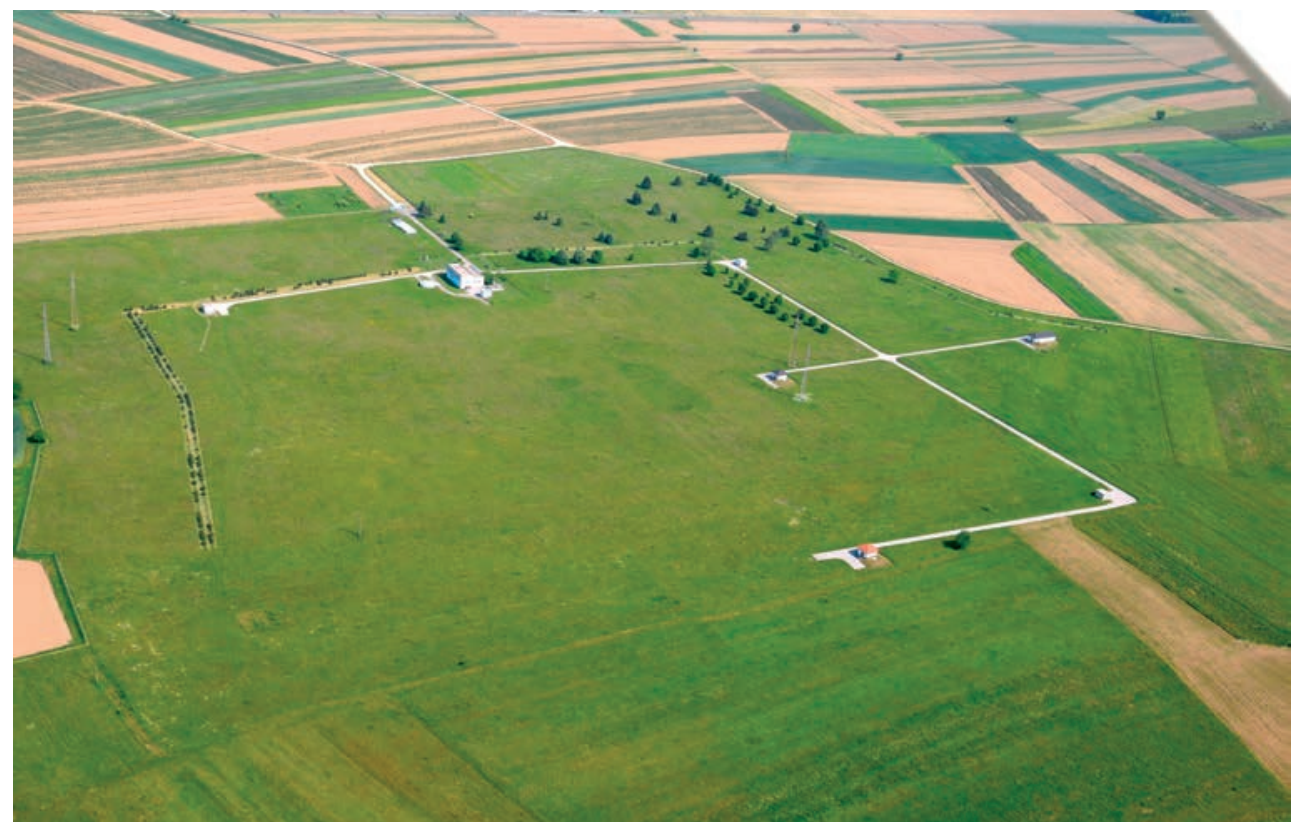

Slika 1. Vodocrpilište Nedelišće

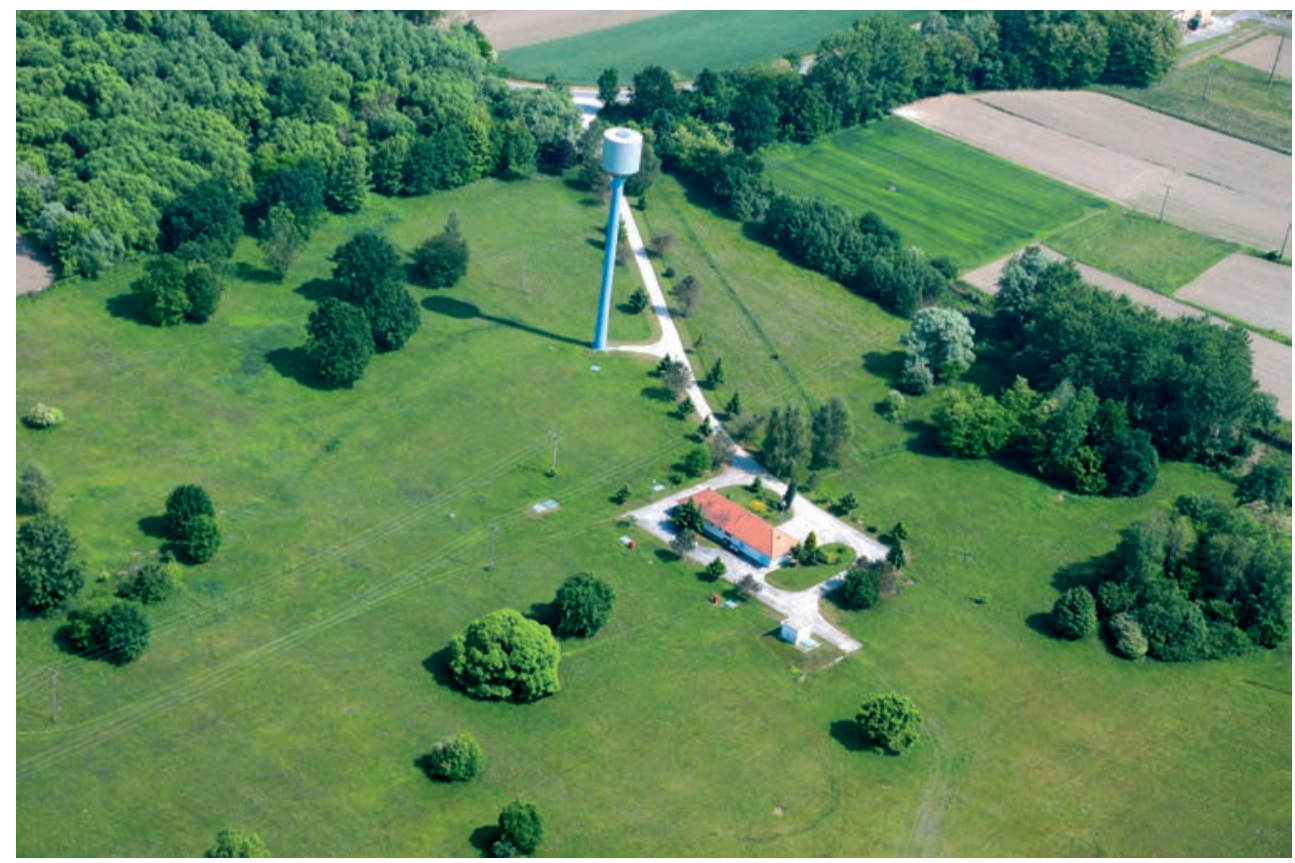

Slika 2. Vodocrpilište Prelog 
zaštitni usjev. 2010. godine bilo je više snježnog pokrivača i godina je bila izrazito kišna, što se odrazilo porastom koncentracije nitrata na 12 mg/L. U studenom 2012. godine došlo je do poplave $u$ Pušćinama, $u$ blizini vodocrpilišta, što je rezultiralo porastom koncentracije nitrata na $16 \mathrm{mg} / \mathrm{L}$. Od 2011. do 2014. poplave i oborine su povećale razinu nitrata (do $12 \mathrm{mg} / \mathrm{L}$ ).

Rezultati koncentracija nitrata za vodocrplište Prelog pokazuju više vrijednosti u odnosu na vodocrpilište Nedelišće, i kreću se od 33 do $37 \mathrm{mg} / \mathrm{L}$ u razdoblju od 2006 do 2014., uz blagi pad do 2010. godine. Podzemna voda iz drugog zdenca na vodocrpilištu Prelog crpi se iz drugog vodonosnog sloja, što objašnjava niže koncentracije nitrata (u odnosu na prvi zdenac), koje se kreću oko $25 \mathrm{mg} / \mathrm{L}$. Više vrijednosti koncentracija nitrata posljedica su intenzivne poljoprivredna proizvodnja na području oko vodocrpilišta. Također, na području druge vodozaštitne zone nije bilo otkupa zemljišta što bi potencijalno moglo utjecati na smanjenje koncentracije nitrata.

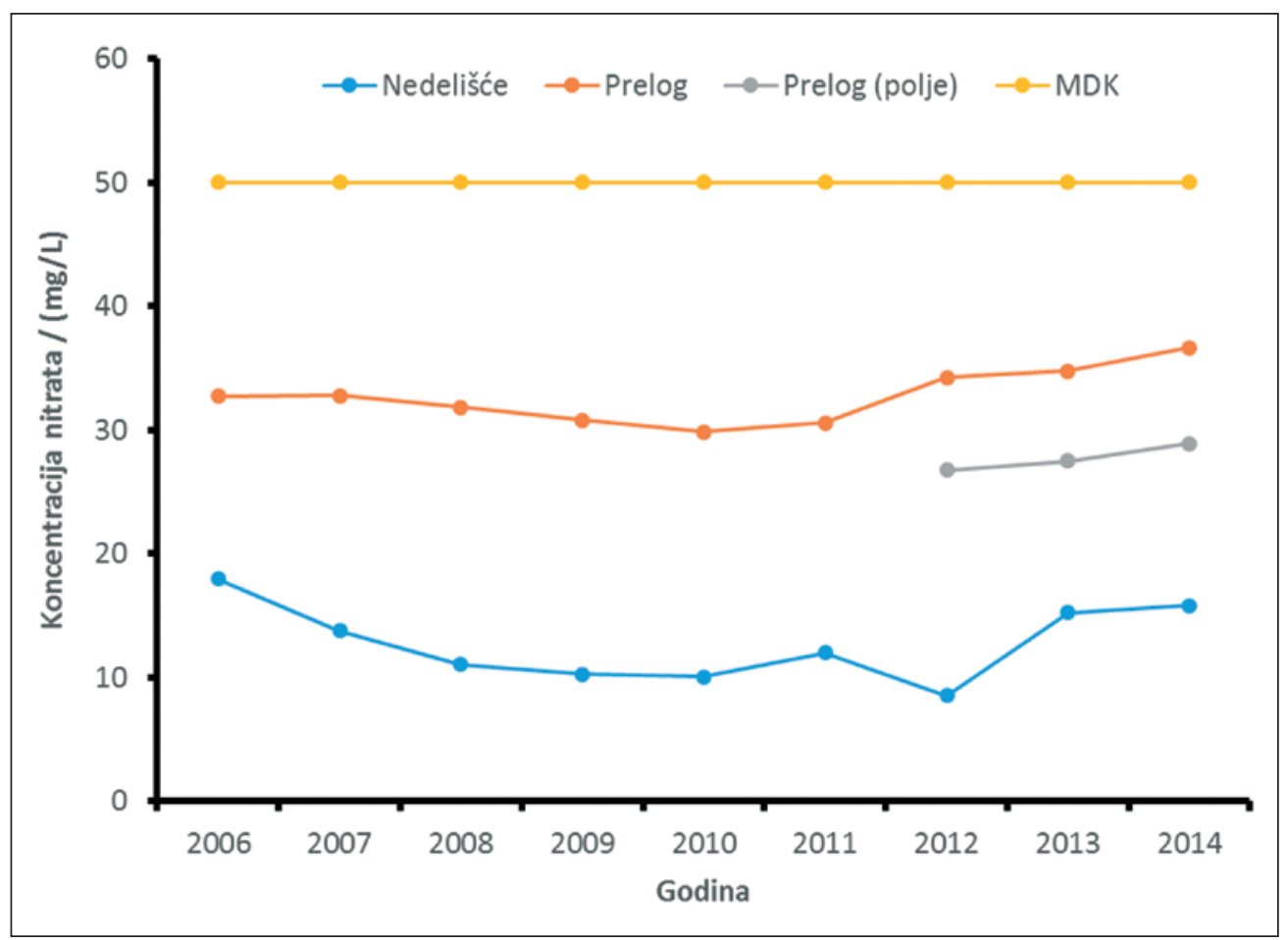

Slika 3. Dinamika prosječne koncentracije nitrata u podzemnoj vodi na crpilištima Nedelišće i Prelog u razdoblju od 2006. do 2014. godine. 
Na slici 4 prikazan je odnos između količine oborina i razine podzemne vode izmjerenih na piezometrima na vodocrpilištu Nedelišće u razdoblju od 2007. do 2014. godine. Podaci za poplavno razdoblje od 2010. do 2014. prikazani su u manjem grafu. Veća količina oborina rezultirala je povećanjem razine podzemnih voda, sa koeficijentom determinacije 0,6575. Na vodocrpilištu Prelog ovakva povezanost nije utvrđena. Podaci za 2006. godinu nisu bili dostupni.

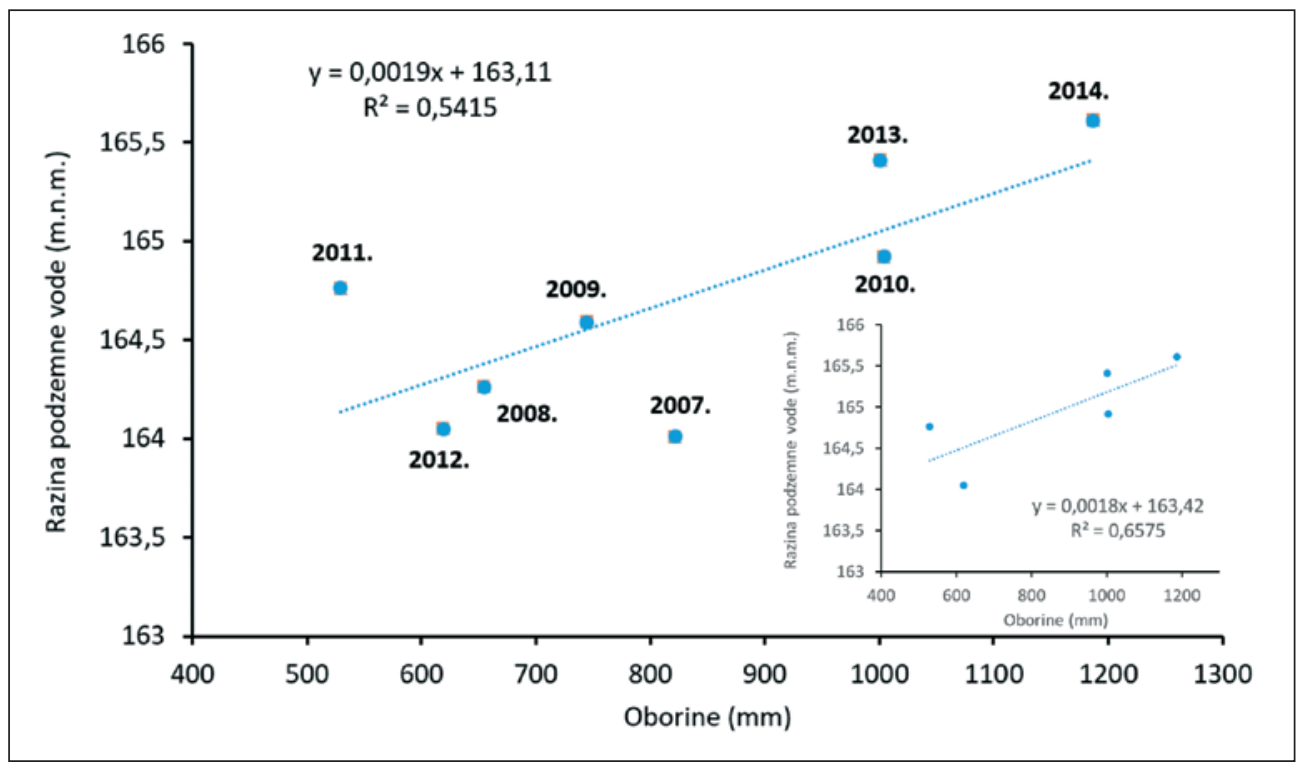

Slika 4. Odnos između količine oborina i razine podzemne vode na crpilištu Nedelišće za razdoblje od 2007. do 2014. godine. Manji graf odnosi se za poplavno razdoblje od 2010. do 2014. godine.

Na slici 5 prikazan je odnos između razine podzemne vode i koncentracije nitrata na vodocrpilištu Nedelišće za razdoblje od 2007. do 2014. godine. Podaci za poplavno razdoblje od 2010. do 2014. prikazani su u manjem grafu. Veća količina oborina uzrokovala je veće ispiranje nitrata i podizanje razine podzemnih voda na vodocrpilištu Nedelišće. Koeficijent determinacije između razine podzemne vode i koncentracije nitrata na crpilištu Nedelišće je 0,8563 , što ukazuje na dobru povezanost razine podzemne vode i koncentracije nitrata koja je povećana ispiranjem tla. Podaci za 2006. godinu nisu bili dostupni. 


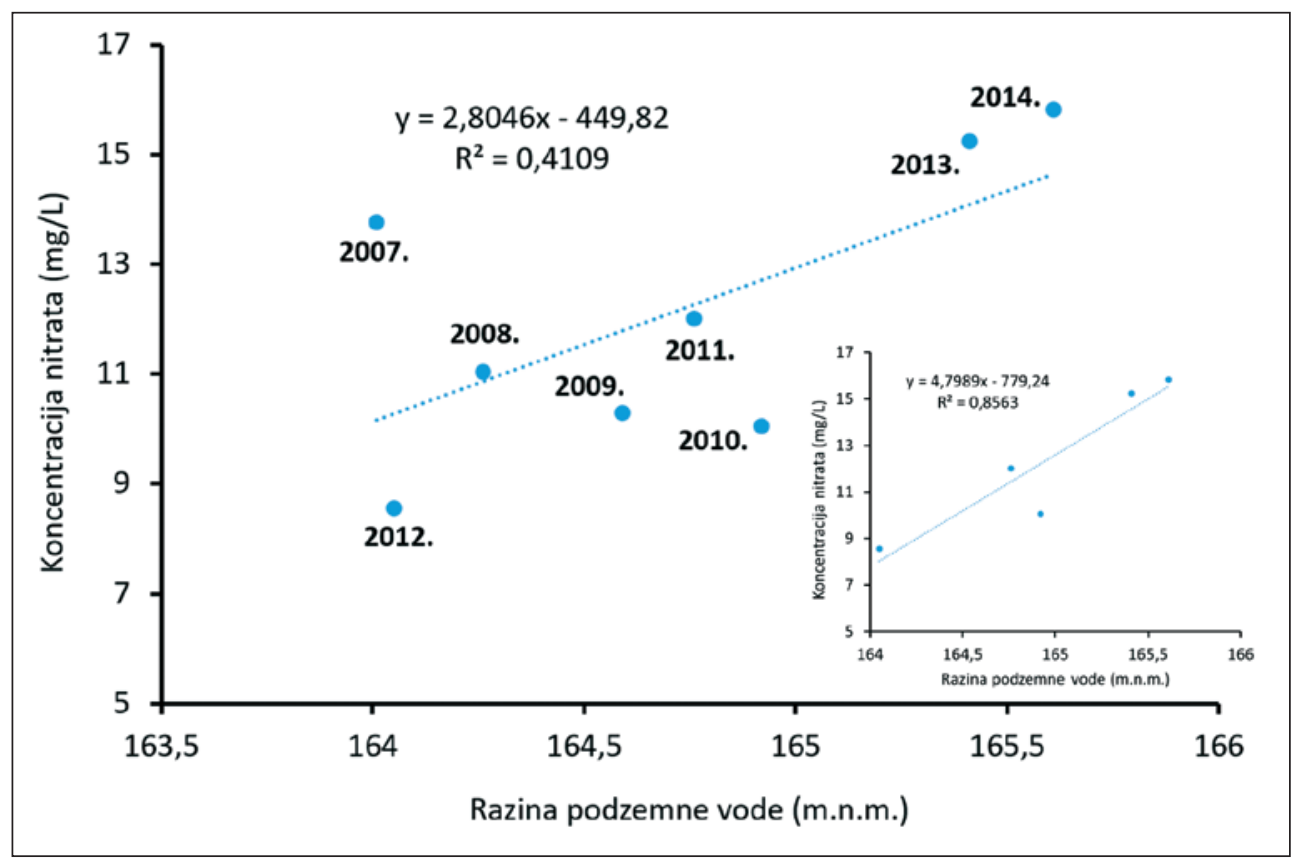

Slika 5. Odnos između razine podzemne vode i koncentracije nitrata na crpilištu Nedelišće za razdoblje od 2007. do 2014. godine. Manji graf odnosi se za poplavno razdoblje od 2010. do 2014. godine.

Na slici 6 prikazani su godišnji prosjeci koncentracije nitrata za zdence Z2 i Z4, te prosjek za sve zdence, na vodocrpilištu Nedelišće za razdoblje od 2006. do 2014. godine. Kod svih zdenaca prisutan je trend smanjivanja koncentracije nitrata do 2010. godine, i rasta do 2014. Razlozi takve dinamike komentirani su uz sliku 3. Najviše vrijednosti koncentracije nitrata nalaze se u zdencu Z2, a kreću se u rasponu od 25 do 15 mg/L - zdenac Z2 je najbliže naselju Hrašćan, te je antropogeni utjecaj najizraženiji. Poplava u Puščinama (2012. godine) posebno je utjecala na zdenac Z2 na kojem su vrijednosti nitrata najviše porasle, skoro dvostruko više od koncentracije nitrata prije poplave. Vrijednosti koncentracije nitrata za zdenac $Z 4$ su najniže, $u$ rasponu od 15 do $7 \mathrm{mg} / \mathrm{L}$. Očito je dakle da je poplava dopremila i odložila sediment površinskog sloja tla s poljoprivrednih površina bogat dušikom - humusom i gnojen mineralnim gnojivima, među kojima i dušičnim. Iz tog sedimenta ispiru se najprije nitrati iz mineralnih gnojiva, a zatim nitrati od mineralizacije humusa. Naša je pretpostavka temeljem toga da poplavni nanos predstavlja točkasti izvor emisije nitrata, vrlo vjerojatno i fosfora, ali se on u tlu dobro veže, i drugih agrokemikalija. 


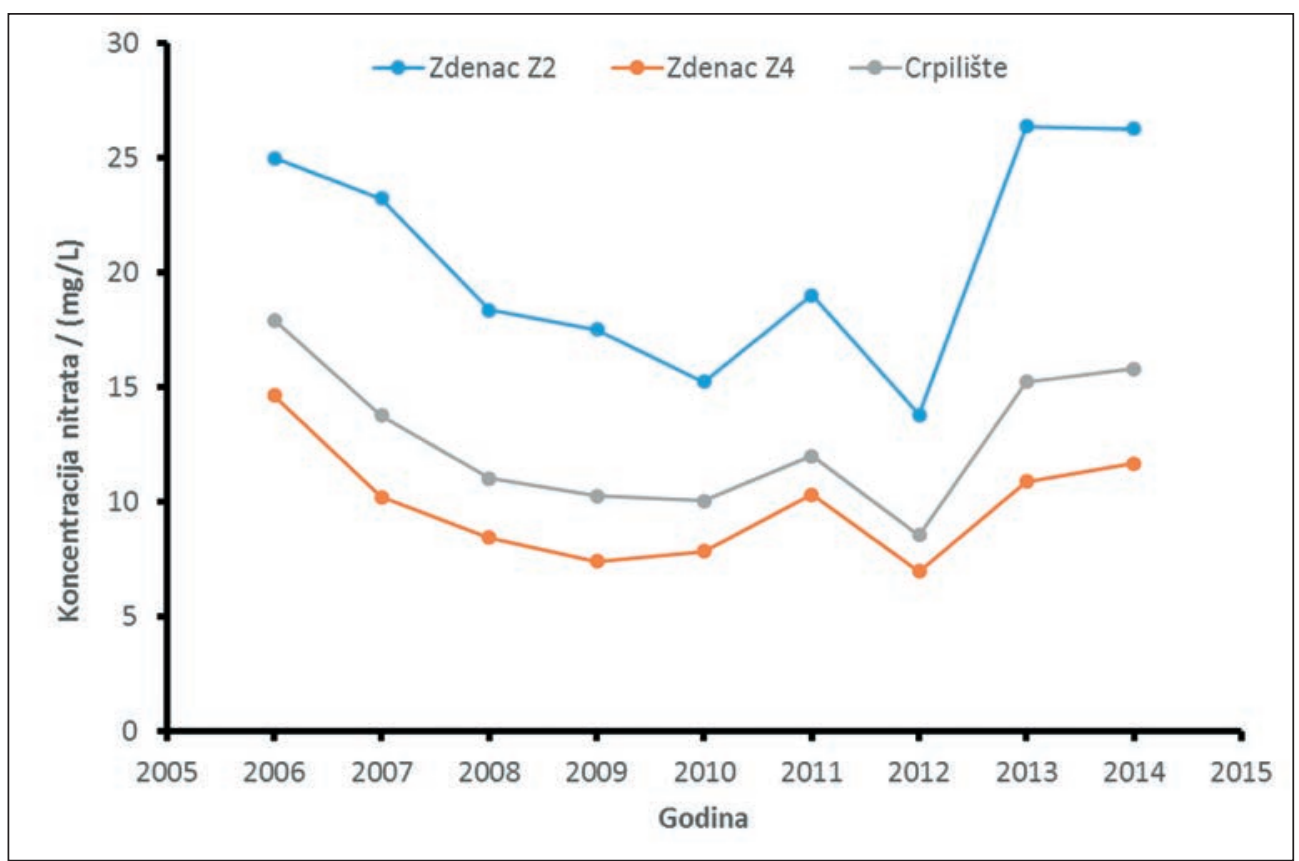

Slika 6. Godišnji prosjeci koncentracije nitrata po zdencima na crpilištu Nedelišće (za razdoblje od 2006. do 2014. godine).

\section{Deterdženti i fosfati}

Vrijednosti koncentracija deterdženata i fosfata na vodocrpilištima Nedelišće i Prelog, u razdoblju od 2006. do 2014., za sve zdence su: a) anionski detergenti $<50 \mu \mathrm{g} / \mathrm{L}, \mathrm{b})$ neionski deterdženti $<50 \mu \mathrm{g} / \mathrm{L}, \mathrm{c})$ fosfati $<100 \mu \mathrm{g} / \mathrm{L}$. Dobiveni podaci vrijednosti koncentracija su bile ispod MDK za cijelo ispitivano razdoblje. Naši rezultati ne ukazuju na utjecaj količine oborina i poplava na sadržaj fosfata i deterdženata u podzemnim vodama oba vodocrpilišta.

\section{ZAKLJUČCI}

Vodocrpilište Nedelišće sadrži niže koncentracije nitrata u odnosu na vodocrpilište Prelog zbog intenzivnije poljoprivredne proizvodnje u priljevnom području crpilišta Prelog.

Od 2006. do 2010. godine koncentracija nitrata bila je u stalnom opadanju. 
Uzgoj crvene djeteline (Trifolium pratense) utječu na smanjenje razine nitrata u vodi zbog velike vegetativne mase djeteline koja u sebe veže dušik.

Od 2011. do 2014. povećana je razina nitrata (do $12 \mathrm{mg} / \mathrm{L}$ ) zbog poplava i veće potrošnje mineralnih gnojiva na poljoprivrednim površinama.

Blizina naselja (Z-2 Nedelišće) i intenzivna poljoprivreda (Prelog) povećavaju razinu nitrata.

Oborine i poplave povećale su razinu podzemnih voda i koncentraciju nitrata.

Oborine i poplave ne utječu na sadržaj fosfata i deterdženata u podzemnoj vodi.

Na osnovu donesenih zaključaka, pri određivanju budućih lokacija za vodocrpilišta, između ostalog, potrebno je uzeti u obzir udaljenost od naselja i poljoprivrednih površina, razinu podzemnih voda, količinu oborina i rizik od poplava.

\section{LITERATURA}

1. Keshav K. DESHMUKH, "Impact of Human Activities on the Quality of Groundwater from Sangamner Area, Ahmednagar District, Maharashtra, India", International Research Journal of Environment Sciences, 2/2013, 66. - 74.

2. Igor HORVAT, Ankica SENTA, Aleksandar RACZ: "Praćenje koncentracije nitrata u vodi Koprivničkog vodovoda", Sigurnost, 52/2010, 359. - 365.

3. Branka VOJNOVIĆ, Ljerka BOKIĆ, Maja KOZINA, Ana KOZINA: „Optimiranje analitičkog postupka određivanja fosfata u detergentima i otpadnim vodama praonica", Tekstil, 56/2007, 147. - 157.

4. http://www.marketsandmarkets.com/PressReleases/surfactants.asp (31.01.2016.)

5. Olivera GALOVIĆ, Mirela SAMARDŽIĆ, Dragan DEREŽIĆ, Dubravka MADUNIĆ-ČAČIĆ, Milan SAK-BOSNAR: "Potentiometric titration of micromolar levels of anionic surfactants in model effluents using a sensitive potentiometric sensor", Int. J. Electrochem. Sci., 7/2012, 1522. - 1531.

6. Mirela SAMARDŽIĆ, Milan SAK-BOSNAR, Dubravka MADUNIĆ-ČAČIĆ: "Simultaneous potentiometric determination of cationic and ethoxylated nonionic surfactants in liquid cleaners and disinfectants", Talanta, 83/2011, 789. - 794.

7. Dubravka MADUNIĆ-ČAČIĆ, Milan SAK-BOSNAR, Olivera GALOVIĆ, Nikola SAKAČ, Ružica MATEŠIĆ-PUAČ: “Determination of cationic surfactants in pharmaceutical disinfectants using a new sensitive potentiometric sensor", Talanta, 76/2008, 259. - 264. 


\section{SAŽETAK \\ DINAMIKA SADRŽAJA NITRATA, FOSFATA I DETERDŽENATA U PODZEMNOJ VODI VODOOPSKRBNOG SUSTAVA MEĐIMURSKE ŽUPANIJE}

Na području Međimurja nalaze se izdašna nalazišta podzemnih voda visoke kakvoće. Podzemne vode crpe se za pitku vodu na dva vodocrpilišta - Nedelišće (šest zdenaca) i Prelog (dva zdenca). U radu su istraživani pokazatelji antropogenog utjecaja na podzemne vode: sadržaj nitrata, fosfata i deterdženata. Analizirani su podaci o laboratorijski utvrđenom sadržaju nitrata, fosfata i deterdženata u podzemnoj vodi od 2006. - 2014. godine na vodocrpilištima Nedelišće i Prelog, prikupljeni podaci o količini oborina i razini podzemnih voda. Voda iz vodocrpilišta Nedelišće sadrži manje koncentracije nitrata u odnosu na onu iz vodocrpilišta Prelog. Od 2006. do 2010. godine koncentracija nitrata bila je u stalnom opadanju. Poslije otkupa zemljišta i uzgoja djeteline na vodocrpilištu Nedelišće došlo je do značajnog smanjenja koncentracije nitrata u vodi. Poplave i oborine 2011. do 2014. godine imale su za posljedicu povećanje koncentraciju nitrata (do $12 \mathrm{mg} / \mathrm{L}$ ). Blizina naselja (zdenac 2, Nedelišće) i intenzivna poljoprivreda (Prelog) povećavaju razinu nitrata. Utvrđene vrijednosti svih analiziranih pokazatelja nalaze se ispod maksimalno dozvoljene koncentracije.

Ključne riječi: nitrati, fosfati i detergenti u pitkoj vodi; poplavni nanos-izvor emisije onečišćenja podzemne vode; crvena djetelina (Trifolium pratense) kao zaštitni usjev.

\section{SUMMARY}

\section{DYNAMICS OF NITRATES, PHOSPHATES AND DETERGENTS IN THE UNDERGROUND WATER OF MEDJIMURJE COUNTY WATER SUPPLY SYSTEM}

Medjimurje county is rich in ground waters. Ground waters are exploited within two water wells - Nedelišće (six wells) and Prelog (two wells). In this paper we investigated some of the main parameters of anthropogenic origin in ground waters: nitrates, phosphates and detergents. We analysed these parameters in a period from 2006 to 2014, on both water wells; Nedelišće and Prelog. We also analysed the influence of the precipitation (quantity and distribution) and flood on ground waters and their correlation with measured parameters. Nitrate concentrations in water well Nedelišće obtained lower concentration compared to water well Prelog. In a period from 2006 to 2010 nitrate concentrations were constantly decreasing. From 2011 to 2014 floods and precipitations caused increase of nitrate concentrations (up to 12 $\mathrm{mg} / \mathrm{L}$ ). The highest nitrate concentrations were observed in well closest to the inhabited area (Nedelišće) and in the area with the intensive agricultural production (Prelog). All investigated parameter concentrations were below maximum acceptable - tolerant concentration.

Key Words: nitrates; phosphates and detergents in drinking groundwaters; flood sediments as hot spots; red clover (Trifolium pratense) as cover crop. 